\title{
Nurses Intervention Regarding Infection Control Measures for Patients with Esophageal Varices During Endoscopy at Zagazig University Hospital

\author{
Wafaa Mohamed Amer ${ }^{1}$, Howida Kameel Zaton ${ }^{2}$, Nadia M. Taha ${ }^{3}$ \\ and Mohamed N. El-khashab ${ }^{4}$ \\ ${ }^{1}$ B.Sc. Nursing, Faculty of Nursing, Zagazig University , Egypt.. \\ ${ }^{2,3}$ Medical Surgical Nursing Department, Faculty of Nursing, Zagazig University, Egypt.. \\ ${ }^{4}$ Tropical medicine Department, Faculty of medicine, Zagazig University,Egypt..
}

\begin{abstract}
Corresponding Author Wafaa Mohammed Amer
\end{abstract}

Mobile: 01002134911

\section{E mail:}

wafaaamer22@yahoo. com

Key words: Intervention Training Program, Gastrointestinal Endoscopy, Infection control, Endoscopy Reprocessing
Background and study aim: Gastrointestinal (GI) endoscopy is an important method for diagnosis and treatment. Endoscopes are complex and reusable devices. Understanding infection control in the context of endoscopy is important in reducing the transmission of infection. The infection control intervention program considers the most effective and important for improving nurses' knowledge and practice regarding infection control measures for patients with esophageal varices during endoscopy. This study aim to evaluate effect of nurses intervention regarding infection control measures for patients with esophageal varices during endoscopy at Zagazig University Hospitals.

Subjects and Methods: A quasi experimental design was used in this study. The study was conducted in endoscopy units at Zagazig University Hospitals. The study sample all available endoscopy nursing staff. The study lasted from the beginning of Jun 2017 to the end March of 2018 .
Results: Revealed that, slightly more than half of nurse's were in the age group of more than 40 years with mean age Mean \pm SD $38.7 \pm 10.7$ years and had more than 10 years of experience. There was improvement in total level of nurses' knowledge $0.0 \%$ pre nursing intervention increased to $100 \%$ post nurses intervention and practice regarding infection control Mean \pm SD 9.8 \pm 3.7 pre nursing intervention increased to Mean \pm SD $96.2 \pm 0.7$ post nurses intervention with highly statistically significant difference between pre and post program regarding to infection control.

Conclusion: It can be concluded that the implantation of health intervention program had improved nurse's knowledge and practice regarding endoscopy infection control. Continuous intervention infection control training programs are recommended in endoscopy units.

\section{INTRODUCTION}

Portal hypertension is a common clinical syndrome, distinct by a pathologic raise in the portal venous pressure, in which the hepatic venous pressure gradient (HVPG) is increased overhead standard values (1-5 mmHg). In cirrhosis, portal hypertension outcomes from the grouping of a raised intrahepatic vascular resistance and excess blood flow over the portal venous system. When the HVPG increases exceeding 10 $\mathrm{mmHg}$, problems of portal hypertension can arise. Consequently, this value characterizes the threshold for defining portal hypertension as being clinically weighty and plays a crucial role in the transition from the preclinical to the clinical phase of the disease $[1,2,3]$.Esophageal variceal bleeding could cause shock, various infections like pneumonia, peritonitis, and bloodstream infection when left untreated [4]. Over half of patients hospitalized because of esophageal variceal bleeding are diagnosed with an infection [5]. The rate of mortality in patients with esophageal variceal bleeding is high at 20-35 percent.

The basic for health care workers is to understanding the predictors for esophageal variceal bleeding, and to recognizing the at threat population for screening [6,7]. It is essential for nursing staff, and the health care group to detect

Amer et al., Afro-Egypt J Infect Endem Dis 2019; 9(1):31-45

https://aeji.journals.ekb.eg/

http://mis.zu.edu.eg/ajied/home.aspx 
lab values and remark the follow lab anomaly, and patient symptoms to a physician.

Endoscopy nurses play a serious role in the donation of safe, high quality endoscopy. Nurses have many responsibilities; to prepare the endoscopic room with the exact device and essential procedures for inspection of the upper or lower GI tract is very vital. It is also essential that the nurse offers the right information about the technique to the patient, to release anxiety and to give descriptions about the modality of the endoscopic process [8].

Throughout the process the nurse should service the endoscopist and, when indicated, the anesthesist. After the completion of the procedure, the nurse should carry-on with the reprocessing of the endoscopic device and of the tools. Specialized and devoted nurses who follow courses to keep up-dated are substantial in this field due to the continuous evolution of the endoscopic instruments and methods. Possible problems must be considered to be documented and to be treated in an early phase. The endoscopy-trained nurse must know the anatomy of the examined segments but must however integrate this knowledge with the care of the patients. Nurses would also donate to clinical investigation concerning endoscopy [9].

\section{SUBJECTS AND METHODS}

Quasi-experimental design was used in carrying out the study to evaluate effect of an intervention program on improving nurse's knowledge and practice regarding infection control measures for patients with patient esophageal varices during endoscopy At Zagazig University Hospital. Field work of this study was executed in 10 months, starting from June 2017 to the end March of 2018.

\section{Hypothesis:}

H1: The mean knowledge scores of nursing regarding caring for patient with esophageal varices during endoscopy post nurses intervention is higher than that of their pre program scores.

H2: The mean practice scores of nursing regarding caring for patient with esophageal varices during endoscopy post nurses intervention is higher than that of their pre intervention scores.

H3: there is a direct relation between nurses' knowledge and their practice scores

\section{Subjects:}

The subjects of the study compromised of all available endoscopy nursing staff (exclude the nurses involved in pilot study) in the mentioned hospital El-Salam University Hospital (14 nurses) and Zagazig University Hospital (21 nurses).

Tools for data collection: two tools were used for data collection:

Tool I: A Structured interview questionnaire tool for nurses was designed by the researcher after revising of related literature and opinions of expertise for content of validity and included the following two parts:

Part 1: Demographic characteristics of nurses e.g. (age, education, occupation, experience in endoscopy unit, training course regarding infection... etc)

Part 2: Endoscopy nurse's knowledge regarding esophageal varices, definition, causes, risk group, diagnosis, complication, treatment, nursing care, Universal Precautions, principles of aseptic technique, hand wash, waste management, nurses knowledge about cleaning, level of disinfection, sterilization, and endoscopy reprocessing.

Tool II: Observational checklist : (pre-post format) To assess nurses' practices before, during, after gastrointestinal endoscopy and discharge instructions.

Tool III: Observational checklist : (pre-post format) Infection control intervention program at the endoscopy unit for endoscopy nurses Pre procedure, during procedure and post procedure (cleaning, rinsing, disinfection, rinsing, drying, and storage).

It was designed by the researcher after revising of related literature to evaluate the nurses' knowledge, and practice related to infection control measures for patient with esophageal varices during endoscopy. The study lasted for 10 months.

\section{Intervention program in endoscopy unit:}

It was designed by the researcher after revising of related literature to evaluate the nurses' knowledge, and practice related to infection control measures for patient with esophageal varices during endoscopy. The study lasted for 10 months.

\section{Content validity and Reliability:}

Content validity was used for the modified tools and the designed booklet to determine whether the tools covered the aim or not. It developed by a jury of 5 experts; four professors from faculty of Nursing, Zagazig University and one from 
Tropical Medicine Department, Faculty of Medicine, Zagazig University. Reliability was done by using Guttman split-half test and retest. It was used to examine whether the observation checklist, compliance assessment scale had internal consistency or not. The test was done and the agreement percentage was $96.2 \%$.

The implementation phase for data collection started as following: The nurses of the data collection, and the implementation of the intervention program lasted over a period of 10 months, starting from July 2017 to march 2018, two months for pre- test (from beginning July, 2017 to the end of August, 2017), Seven months implementation the program and posttest (from beginning of August 2017 to end of February 2018), one month after posttest was done (from beginning of March to end of March 2018). The questionnaire sheet was designed by the researcher. Data used was collected four days from the endoscopy unit, from 9:00 am to 1:00 pm where the program was implemented. Nurses were grouped; each group included 4-5 nurse. It was necessary for the researcher to introduce herself for the nurse and explain the purpose of the study. The data was collected in a simplified Arabic language. The study program consisted of 16 sessions; one session of them to identify the objective and the importance of the program. One third of the sessions (5) were theoretical, and two thirds (9) were practical and one session for revision. Each interview took approximately 30 minutes in each theoretical session and 30- 45 minutes in each practical session. The theoretical sessions were followed by practical sessions.

\section{Administrative and Ethical considerations:}

The study was ethically approved from the dean of the faculty of Nursing, the manager of Zagazig University Hospitals and from the head of Endoscopy Unit.

\section{Statistical Design:}

All collected data were organized, categorized, tabulated, entered, and analyzed by using SPSS (Statistical Package for Social Sciences); a software program version 14 , which was applied to frequency tables and statistical significance. The statistical significance and associations were assessed using, the arithmetic mean, the standard deviation (SD), Wilcoxon Signed Ranks test (Z test), Independent sample $t$ test ( $T$ test), Pearson Chi-square test (X2) and Pearson Correlation (r) to detect the relation between the variables.

\section{RESULTS}

The first part of our results was the demographic characteristics of. It was found that $60 \%$ of nurses were in the age group of less than 40 years with mean age $38.7 \pm 10.7$ years. Regarding nursing qualification $88.6 \%$ of the studied nurses had diploma in nursing while $11.4 \%$ had bachelor in Nursing. As well as $54.3 \%$ of the studied nurses had less than 10 years of experience in hematemesis unit with mean \pm SD $7.6 \pm 5.7$ years. In relation to the attended training courses $51.4 \%$ received training. Regarding to hepatitis $\mathrm{B}$ vaccination $97.1 \%$ of study nurses received the vaccine. (Table 1).

The second part of our results was concerned with the highly statistically significance of practice level regarding prepare and place equipment on special clean table and wearing sterile gloves before procedures when comparing with pre and post of implementation of intervention program $(\mathrm{p} \leq 0.001)$ (Table 2).

The third part of our results was concerned with the highly statistically significance of practice level regarding during procedure: adherence to infection control principles restrictedly, post procedure pre-cleaning : wipe the insertion tube with an enzymatic detergent, suction enzymatic detergent through the instrument channel for 30 seconds, suction air through the instrument channel for 10 seconds, attach the air/water channel cleaning adapter; depress to feed water through the air and water channels for 10 seconds, use the special cleaning adapters as recommended in the endoscope instruction manuals for pre-cleaning, discard disposable valves, place valves and removable parts in beaker of detergent solution, inspect and attach the water resistant cap when comparing with pre and post of implementation of intervention program, at $(p \leq 0.001)$. While there was no significant statistically difference in nurse's practice regarding cover the endoscope and transport to the reprocessing area $(\mathrm{p}=1.00)($ Table 3$)$.

The fourth portion of our results was concerned with the highly statistically significance of practice level regarding post procedure: all table items for leakage testing: when comparing with pre and post of implementation of intervention program, at $(\mathrm{p} \leq 0.001)($ Table 4$)$.

The fifth portion of our results was concerned with the highly statistically significance of practice level regarding post procedure: all table items for 
manual cleaning when comparing with pre and post of implementation of intervention program $(p \leq 0.001)$.While there is no statistically significant difference in nurse's practice regarding to immerse the entire endoscope in freshly prepared enzymatic detergent solution ( $\mathrm{p}=1.00)$ (Table 5).

The sixth portion of our results was concerned with the highly statistically significance of practice level regarding post procedure: all table items for high level disinfectant (HLD): exposure time and temperature varies among FDA approved high level disinfectants, name and type of high level disinfectant: when comparing with pre and post of implementation of intervention program $(\mathrm{p} \leq 0.001)$ (Table 6).

The seventh portion of our results demonstrated that there were highly statistically significance of practice level regarding to post procedure: manual disinfection when comparing with pre and post of implementation of intervention program $(\mathrm{p} \leq$ 0.001) (Tables 7).

The eighth portion of our results demonstrated that there were highly statistically significance of practice level regarding post procedure: endoscope handling: ensure that the insertion tube is not coiled too tightly when handling the endoscope, position the control knobs upright, especially if the endoscope is placed on a counter, transport the endoscope using both hands, for endoscopes with flexibility adjustment, ensure the insertion tube is set to maximum flexibility, disinfected scopes are properly hung and dried away from dirty reprocessing areas with pre and post of implementation of intervention program $(\mathrm{p} \leq$ 0.001 ). While there was no statistically significant difference in nurse's practice regarding to endoscope storage: ensure that an alcohol flush was performed and that the endoscope was dried with a lint free cloth and alcohol, remove all valves and removable parts from the endoscope to prevent the retention of moisture, store the endoscope with the angulation locks in the free position, in a ventilated cabinet, hang the endoscope with the insertion tube and light guide tube placed vertical (support the control body) ( $\mathrm{p}=1.00)$ (Tables 8). 
Table (1): Demographic characteristics of nurses in the study sample (n=35)

\begin{tabular}{|c|c|c|}
\hline & Frequency & Percent \\
\hline \multicolumn{3}{|l|}{ Age: } \\
\hline$<40$ & 21 & 60.0 \\
\hline $40+$ & 14 & 40.0 \\
\hline Range & \multicolumn{2}{|c|}{$26.0-58.0$} \\
\hline Mean \pm SD & \multicolumn{2}{|c|}{$38.7 \pm 10.7$} \\
\hline Median & \multicolumn{2}{|c|}{35.0} \\
\hline \multicolumn{3}{|c|}{ Nursing qualification: } \\
\hline Diploma & 31 & 88.6 \\
\hline Bachelor & 4 & 11.4 \\
\hline \multicolumn{3}{|c|}{ Experience years in nursing: } \\
\hline$<20$ & 22 & 62.9 \\
\hline $20+$ & 13 & 37.1 \\
\hline Range & \multicolumn{2}{|c|}{$7.0-35.0$} \\
\hline Mean \pm SD & \multicolumn{2}{|c|}{15.0} \\
\hline \multicolumn{3}{|l|}{ Median } \\
\hline \multicolumn{3}{|c|}{ Experience years in hematemesis unit: } \\
\hline$<10$ & 19 & 54.3 \\
\hline $10+$ & 16 & 45.7 \\
\hline Range & \multicolumn{2}{|c|}{$0.0-21.0$} \\
\hline Mean \pm SD & \multicolumn{2}{|c|}{$7.6 \pm 5.7$} \\
\hline Median & \multicolumn{2}{|c|}{8.0} \\
\hline \multicolumn{3}{|c|}{ Experience years in endoscopy unit: } \\
\hline$<5$ & 18 & 51.4 \\
\hline $5+$ & 17 & 48.6 \\
\hline Range & \multicolumn{2}{|c|}{$0.0-25.0$} \\
\hline Mean \pm SD & \multicolumn{2}{|c|}{$5.7 \pm 6.0$} \\
\hline Median & \multicolumn{2}{|c|}{4.0} \\
\hline \multicolumn{3}{|c|}{ Attended training courses: } \\
\hline No & 17 & 48.6 \\
\hline Yes & 18 & 51.4 \\
\hline \multicolumn{3}{|c|}{ Had HBV vaccination: } \\
\hline No & 1 & 2.9 \\
\hline Yes & 34 & 97.1 \\
\hline
\end{tabular}


Table (2) : Nurses' practice of infection control precautions before procedure (prepare equipment) throughout intervention

\begin{tabular}{|c|c|c|c|c|c|c|}
\hline \multirow{3}{*}{$\begin{array}{l}\text { Infection control precautions } \\
\text { Done }\end{array}$} & \multicolumn{4}{|c|}{ Time } & \multirow{3}{*}{$\begin{array}{l}\mathrm{X} 2 \\
\text { test }\end{array}$} & \multirow{3}{*}{ p-value } \\
\hline & \multicolumn{2}{|c|}{$\begin{array}{c}\text { Pre } \\
(\mathbf{n}=35)\end{array}$} & \multicolumn{2}{|c|}{$\begin{array}{c}\text { Post } \\
(\mathbf{n}=35)\end{array}$} & & \\
\hline & No. & $\%$ & No. & $\%$ & & \\
\hline \multicolumn{7}{|l|}{$\begin{array}{l}\text { Before procedure } \\
\text { A) Prepare and place equipment on special clean table } \\
\text { B) Wear sterile gloves: }\end{array}$} \\
\hline $\begin{array}{l}\text { Remove outer glove package wrapper by carefully } \\
\text { separating and peeling apart sides. }\end{array}$ & 0 & 0.0 & 35 & 100.0 & 70.00 & $<0.001^{*}$ \\
\hline $\begin{array}{l}\text { Grasp inner package and lay it on clean and flat } \\
\text { surface }\end{array}$ & 0 & 0.0 & 35 & 100.0 & 70.00 & $<0.001^{*}$ \\
\hline $\begin{array}{l}\text { Open package, keeping gloves on wrapper's inside } \\
\text { surface }\end{array}$ & 0 & 0.0 & 35 & 100.0 & 70.00 & $<0.001^{*}$ \\
\hline $\begin{array}{l}\text { With thumb and first two fingers, grasp edge of cuff of } \\
\text { glove, touch only glove's inside surface. }\end{array}$ & 0 & 0.0 & 35 & 100.0 & 70.00 & $<0.001^{*}$ \\
\hline $\begin{array}{l}\text { Pull glove over dominant hand, leaving cuff and not } \\
\text { roll up wrist }\end{array}$ & 0 & 0.0 & 35 & 100.0 & 70.00 & $<0.001^{*}$ \\
\hline $\begin{array}{l}\text { With glove dominant hand, slip fingers underneath } \\
\text { second glove's cuff }\end{array}$ & 0 & 0.0 & 35 & 100.0 & 70.00 & $<0.001^{*}$ \\
\hline $\begin{array}{l}\text { Pull second glove over non dominant hand without } \\
\text { allow Fingers and thumb of gloved dominant hand to } \\
\text { touch any part of exposed non dominant hand. }\end{array}$ & 0 & 0.0 & 11 & 31.4 & 13.05 & $<0.001^{*}$ \\
\hline Interlock hands, touch only sterile sites & 0 & 0.0 & 35 & 100.0 & 70.00 & $<0.001^{*}$ \\
\hline
\end{tabular}

(*) Statistically significant at $\mathbf{p}<0.05$

Table (3): Nurses' practice of infection control precautions during and post procedure throughout intervention

\begin{tabular}{|c|c|c|c|c|c|c|}
\hline \multirow{3}{*}{$\begin{array}{l}\text { Infection control precautions } \\
\text { Done }\end{array}$} & \multicolumn{4}{|c|}{ Time } & \multirow{3}{*}{$\underset{\text { test }}{\mathbf{X 2}}$} & \multirow{3}{*}{ p-value } \\
\hline & \multicolumn{2}{|c|}{$\begin{array}{c}\text { Pre } \\
(\mathbf{n}=35)\end{array}$} & \multicolumn{2}{|c|}{$\begin{array}{c}\text { Post } \\
(n=35)\end{array}$} & & \\
\hline & No. & $\%$ & No. & $\%$ & & \\
\hline \multicolumn{7}{|l|}{ During Procedure } \\
\hline Adherence to infection control principles restrictedly & 1 & 2.9 & 35 & 100.0 & 66.11 & $<0.001^{*}$ \\
\hline \multicolumn{7}{|l|}{ Post procedure Pre-Cleaning: } \\
\hline $\begin{array}{l}\text { Perform pre-cleaning in the procedure room } \\
\text { immediately after each procedure. }\end{array}$ & $\overline{9}$ & 25.7 & 35 & 100.0 & 41.36 & $<0.001^{*}$ \\
\hline Wipe the insertion tube with an enzymatic detergent & 0 & 0.0 & 35 & 100.0 & 70.00 & $<0.001^{*}$ \\
\hline $\begin{array}{l}\text { Suction enzymatic detergent through the instrument } \\
\text { channel for } 30 \text { seconds. }\end{array}$ & 0 & 0.0 & 35 & 100.0 & 70.00 & $<0.001^{*}$ \\
\hline $\begin{array}{l}\text { Suction air through the instrument channel for } 10 \\
\text { seconds }\end{array}$ & 0 & 0.0 & 35 & $\overline{100.0}$ & 70.00 & $<0.001^{*}$ \\
\hline $\begin{array}{l}\text { Attach the air/water channel cleaning adapter; } \\
\text { depress to feed water thru the air and water channels } \\
\text { for } 10 \text { seconds }\end{array}$ & $\overline{0}$ & 0.0 & 35 & 100.0 & 70.00 & $<0.001^{*}$ \\
\hline $\begin{array}{l}\text { Use the special cleaning adapters as recommended in } \\
\text { the endoscope instruction manuals for pre-cleaning }\end{array}$ & 0 & 0.0 & 35 & $\overline{100.0}$ & 70.00 & $<0.001^{*}$ \\
\hline Discard disposable valves. & $\overline{0}$ & 0.0 & 35 & 100.0 & 70.00 & $<0.001^{*}$ \\
\hline $\begin{array}{l}\text { Place valves and removable parts in beaker of } \\
\text { detergent solution }\end{array}$ & 0 & 0.0 & 35 & $\overline{100.0}$ & 70.00 & $<0.001^{*}$ \\
\hline Inspect and attach the water resistant cap. & 0 & 0.0 & 35 & 100.0 & 70.00 & $<0.001^{*}$ \\
\hline $\begin{array}{l}\text { Cover the endoscope and transport to the } \\
\text { reprocessing area }\end{array}$ & 34 & 97.1 & 35 & $\overline{100.0}$ & Fisher & $\overline{1.00}$ \\
\hline
\end{tabular}

(*) Statistically significant at $\mathbf{p}<0.05$ 
Table (4): Nurses' practice of infection control precautions post procedure (leakage testing) throughout intervention

\begin{tabular}{|c|c|c|c|c|c|c|}
\hline \multirow{3}{*}{$\begin{array}{c}\text { Infection control precautions } \\
\text { Done }\end{array}$} & \multicolumn{4}{|c|}{ Time } & \multirow{3}{*}{$\begin{array}{l}\text { X2 } \\
\text { test }\end{array}$} & \multirow{3}{*}{ p-value } \\
\hline & \multicolumn{2}{|c|}{$\begin{array}{c}\text { Pre } \\
(\mathbf{n}=35)\end{array}$} & \multicolumn{2}{|c|}{$\begin{array}{c}\text { Post } \\
(\mathbf{n}=35)\end{array}$} & & \\
\hline & No. & $\%$ & No. & $\%$ & & \\
\hline \multicolumn{7}{|l|}{$\begin{array}{l}\text { Post procedure: } \\
\text { Leakage Testing: }\end{array}$} \\
\hline $\begin{array}{l}\text { Perform leakage testing in the reprocessing area, prior } \\
\text { to reprocessing each endoscope. }\end{array}$ & 0 & 0.0 & 35 & 100.0 & 70.00 & $<0.001 *$ \\
\hline $\begin{array}{l}\text { Wear appropriate personal protective equipment } \\
\text { (PPE) }\end{array}$ & 0 & 0.0 & 29 & 82.9 & 49.51 & $<0.001^{*}$ \\
\hline Fill basin or sink with clean water for leakage testing. & 0 & 0.0 & 35 & 100.0 & 70.00 & $<0.001 *$ \\
\hline $\begin{array}{l}\text { Connect the leakage tester connector to the output } \\
\text { socket on the light source }\end{array}$ & 0 & 0.0 & 29 & 82.9 & 49.51 & $<0.001^{*}$ \\
\hline $\begin{array}{l}\text { Check that the leakage tester is emitting air and } \\
\text { confirm that the connector cap is dry. }\end{array}$ & 0 & 0.0 & 35 & 100.0 & 70.00 & $<0.001^{*}$ \\
\hline $\begin{array}{l}\text { Attach the leakage tester's connector to the water } \\
\text { resistant cap and verify that the endoscope is } \\
\text { pressurized }\end{array}$ & 0 & 0.0 & 35 & 100.0 & 70.00 & $<0.001 *$ \\
\hline $\begin{array}{l}\text { Immerse the entire endoscope in the water and } \\
\text { observe for } 30 \text { seconds, visually inspect for potential } \\
\text { leaks }\end{array}$ & 0 & 0.0 & 35 & 100.0 & 70.00 & $<0.001 *$ \\
\hline $\begin{array}{l}\text { Manipulate the angulations knobs and video switches } \\
\text { to check for potential leaks. }\end{array}$ & 0 & 0.0 & 35 & 100.0 & 70.00 & $<0.001 *$ \\
\hline $\begin{array}{l}\text { Remove the endoscope from the water and then turn } \\
\text { off the air supply }\end{array}$ & 0 & 0.0 & 35 & 100.0 & 70.00 & $<0.001^{*}$ \\
\hline $\begin{array}{l}\text { Disconnect the leakage tester for the air supply and } \\
\text { allow the endoscope to depressurize. }\end{array}$ & 0 & 0.0 & 35 & 100.0 & 70.00 & $<0.001 *$ \\
\hline $\begin{array}{l}\text { Disconnect the leakage tester from the water resistant } \\
\text { cap (Do not remove the water resistant cap) }\end{array}$ & 0 & 0.0 & 80 & 80.0 & 46.67 & $<0.001 *$ \\
\hline Dry the leakage tester connector cap. & 0 & 0.0 & 35 & 100.0 & 70.00 & $<0.001 *$ \\
\hline
\end{tabular}

(*) Statistically significant at $\mathbf{p}<\mathbf{0 . 0 5}$ 
Table (5) : Nurses' practice of infection control precautions post procedure (manual cleaning) throughout intervention

\begin{tabular}{|c|c|c|c|c|c|c|}
\hline \multirow{3}{*}{$\begin{array}{l}\text { Infection control precautions } \\
\text { Done }\end{array}$} & \multicolumn{4}{|c|}{ Time } & \multirow{3}{*}{$\begin{array}{l}\mathrm{X} 2 \\
\text { test }\end{array}$} & \multirow{3}{*}{ p-value } \\
\hline & \multicolumn{2}{|c|}{$\begin{array}{c}\text { Pre } \\
(\mathbf{n}=35)\end{array}$} & \multicolumn{2}{|c|}{$\begin{array}{c}\text { Post } \\
(\mathbf{n}=35)\end{array}$} & & \\
\hline & No. & $\%$ & No. & $\%$ & & \\
\hline \multicolumn{7}{|l|}{$\begin{array}{l}\text { Post procedure: } \\
\text { Manual Cleaning: }\end{array}$} \\
\hline $\begin{array}{l}\text { Immerse the entire endoscope in freshly prepared } \\
\text { enzymatic detergent solution. }\end{array}$ & 34 & 97.1 & 35 & 100.0 & Fisher & 1.00 \\
\hline What type of enzymatic detergent is being used? & $\overline{0}$ & 0.0 & 26 & 74.3 & 41.36 & $<0.001^{*}$ \\
\hline $\begin{array}{l}\text { Does the staff have written manufacturer's (mfr) } \\
\text { instructions for use of the enzymatic detergent? }\end{array}$ & 0 & 0.0 & 35 & 100.0 & 70.00 & $<0.001^{*}$ \\
\hline $\begin{array}{l}\text { Is enzymatic detergent beginning diluted to the } \\
\text { manufacturer's (mfr) recommendations? }\end{array}$ & 0 & 0.0 & 35 & 100.0 & 70.00 & $<0.001^{*}$ \\
\hline $\begin{array}{l}\text { Is the sink marked for proper level of water to } \\
\text { achieve proper concentration of enzymatic detergent } \\
\text { solution? }\end{array}$ & 0 & 0.0 & 27 & 77.1 & 43.95 & $<0.001^{*}$ \\
\hline $\begin{array}{l}\text { Is the enzymatic detergent freshly prepared for one } \\
\text { time use with each scope and discarded after one } \\
\text { time use? }\end{array}$ & 0 & 0.0 & 27 & 77.1 & 43.95 & $<0.001^{*}$ \\
\hline $\begin{array}{l}\text { Brush biopsy/suction channel in the insertion tube } \\
\text { with the channel cleaning brush until all debris is } \\
\text { removed. }\end{array}$ & 0 & 0.0 & 35 & 100.0 & 70.00 & $<0.001^{*}$ \\
\hline $\begin{array}{l}\text { Brush biopsy/suction channel in the universal cord } \\
\text { with channel cleaning brush until all debris is } \\
\text { removed. }\end{array}$ & $\overline{0}$ & 0.0 & 35 & 100.0 & 70.00 & $<0.001^{*}$ \\
\hline $\begin{array}{l}\text { Brush suction valve housing and instrument channel } \\
\text { port with channel opening brush until all debris is } \\
\text { removed. }\end{array}$ & $\overline{0}$ & 0.0 & 35 & 100.0 & 70.00 & $<0.001^{*}$ \\
\hline $\begin{array}{l}\text { Use suction channel cleaning adapter to suction } \\
\text { detergent through the suction/biopsy channel for } 30 \\
\text { sec. }\end{array}$ & 0 & 0.0 & 35 & 100.0 & 70.00 & $<0.001^{*}$ \\
\hline $\begin{array}{l}\text { Attach the channel plug and injection tube and inject } \\
\text { detergent through the air/water channel. }\end{array}$ & 0 & 0.0 & 35 & 100.0 & 70.00 & $<0.001^{*}$ \\
\hline Use all channel cleaning adapters and brushes & 0 & 0.0 & 35 & 100.0 & 70.00 & $<0.001^{*}$ \\
\hline $\begin{array}{l}\text { Disconnect the channel plug, injection tube, and } \\
\text { special cleaning adapters. }\end{array}$ & 0 & 0.0 & 35 & 100.0 & 70.00 & $<0.001^{*}$ \\
\hline Soak the endoscope in the detergent solution. & 0 & 0.0 & 35 & 100.0 & 70.00 & $<0.001^{*}$ \\
\hline $\begin{array}{l}\text { Brush and flush the valves, and removable parts } \\
\text { using a clean lint free cloth. }\end{array}$ & 0 & 0.0 & 35 & 100.0 & 70.00 & $<0.001^{*}$ \\
\hline $\begin{array}{l}\text { Thoroughly dry the exterior of the endoscope and all } \\
\text { removable parts using a clean lint free cloth. }\end{array}$ & 0 & 0.0 & 35 & 100.0 & 70.00 & $<0.001^{*}$ \\
\hline $\begin{array}{l}\text { Inspect the endoscope for residual debris and repeat } \\
\text { the manual cleaning process if debris remains. }\end{array}$ & 0 & 0.0 & 35 & 100.0 & 70.00 & $<0.001^{*}$ \\
\hline $\begin{array}{l}\text { Does the center use single use scope cleaning } \\
\text { brushes? If so, are they being RE-USED? This } \\
\text { practice needs to stop immediately. }\end{array}$ & 0 & 0.0 & 35 & 100.0 & 70.00 & $<0.001^{*}$ \\
\hline $\begin{array}{l}\text { Does the center use re-usable scope cleaning brushes } \\
\text { - labeled as re-usable by mfr? If so, are they } \\
\text { reprocessing according to mfr directions? }\end{array}$ & 0 & 0.0 & 35 & 100.0 & 70.00 & $<0.001^{*}$ \\
\hline $\begin{array}{l}\text { Prepare compatible valves and removable parts for } \\
\text { steam sterilization or HLD. }\end{array}$ & 0 & 0.0 & 35 & 100.0 & 70.00 & $<0.001^{*}$ \\
\hline
\end{tabular}

(*) Statistically significant at $\mathbf{p}<0.05$ 
Table (6) : Nurses' practice of infection control precautions post procedure (high level disinfection) throughout intervention

\begin{tabular}{|c|c|c|c|c|c|c|}
\hline \multirow{3}{*}{$\begin{array}{l}\text { Infection control precautions } \\
\text { Done }\end{array}$} & \multicolumn{4}{|c|}{ Time } & \multirow{3}{*}{$\begin{array}{l}\text { X2 } \\
\text { test }\end{array}$} & \multirow{3}{*}{ p-value } \\
\hline & \multicolumn{2}{|c|}{$\begin{array}{c}\text { Pre } \\
(\mathbf{n}=35)\end{array}$} & \multicolumn{2}{|c|}{$\begin{array}{c}\text { Post } \\
(\mathbf{n}=35)\end{array}$} & & \\
\hline & & $\%$ & No. & $\%$ & & \\
\hline \multicolumn{7}{|l|}{ Post procedure: } \\
\hline \multicolumn{7}{|l|}{$\begin{array}{l}\text { High Level Disinfectant (HLD): Exposure time and } \\
\text { temperature varies among FDA approved high level } \\
\text { disinfectants }\end{array}$} \\
\hline Name and type of high level disinfectant: & 0 & 0.0 & 34 & $\begin{array}{l}97.1 \\
\end{array}$ & 62.23 & $<0.001^{*}$ \\
\hline $\begin{array}{l}\text { Verify the correct exposure time for HLD per } \mathrm{mfr} \\
\text { instructions }\end{array}$ & $\overline{0}$ & $\overline{0.0}$ & 35 & $\overline{100.0}$ & $\overline{70.00}$ & $<0.001^{*}$ \\
\hline $\begin{array}{l}\text { Verify the temperature required for HLD per mfr } \\
\text { instructions }\end{array}$ & 0 & $\overline{0.0}$ & 35 & 100.0 & 70.00 & $<0.001^{*}$ \\
\hline $\begin{array}{l}\text { Verify that the Center has a copy of all written mfr } \\
\text { instructions for use on ALL equipment and supplies } \\
\text { used for re-processing }\end{array}$ & 0 & $\overline{0.0}$ & 35 & 100.0 & 70.00 & $<0.001^{*}$ \\
\hline $\begin{array}{l}\text { Confirm the HLD is labeled and changed out } \\
\text { according to the mfr recommendations. In use start and } \\
\text { expiration dates need to be } \\
\text { documented }\end{array}$ & 0 & $\overline{0.0}$ & 35 & 100.0 & 70.00 & $<0.001^{*}$ \\
\hline $\begin{array}{l}\text { Confirm that HLD is discarded at the maximum days } \\
\text { of re-use and/or when quality control testing shows } \\
\text { failure of the Minimum Effective Concentration (MEC) }\end{array}$ & $\overline{0}$ & 0.0 & 35 & 100.0 & 70.00 & $<0.001^{*}$ \\
\hline
\end{tabular}

(*) Statistically significant at $\mathbf{p}<0.05$

Table (7) : Nurses' practice of infection control precautions post procedure (manual disinfection) throughout intervention

\begin{tabular}{|c|c|c|c|c|c|c|}
\hline \multirow{3}{*}{$\begin{array}{l}\text { Infection control precautions } \\
\text { Done }\end{array}$} & \multicolumn{4}{|c|}{ Time } & \multirow{3}{*}{$\begin{array}{l}\text { X2 } \\
\text { test }\end{array}$} & \multirow{3}{*}{ p-value } \\
\hline & \multicolumn{2}{|c|}{$\begin{array}{c}\text { Pre } \\
(\mathbf{n}=35)\end{array}$} & \multicolumn{2}{|c|}{$\begin{array}{c}\text { Post } \\
(\mathbf{n}=35)\end{array}$} & & \\
\hline & & $\%$ & No. & $\%$ & & \\
\hline \multicolumn{7}{|l|}{$\begin{array}{l}\text { Post procedure: } \\
\text { Manual Disinfecting: }\end{array}$} \\
\hline $\begin{array}{l}\text { Test the HLD minimum effective concentration } \\
\text { (MEC) with each use. }\end{array}$ & 0 & 0.0 & 35 & $\overline{100.0}$ & $\overline{70.00}$ & $<0.001^{*}$ \\
\hline Immerse the entire endoscope in a basin of HLD solution & 1 & 2.9 & 35 & 100.0 & 66.11 & $<0.001^{*}$ \\
\hline $\begin{array}{l}\text { Attach the adapters (channel plug, injection tube, and } \\
\text { special cleaning adapters) }\end{array}$ & 1 & 2.9 & 35 & $\overline{100.0}$ & 66.11 & $<0.001^{*}$ \\
\hline Flush the HLD solution to purge air from all channels & 1 & 2.9 & 35 & 100.0 & 66.11 & $<0.001^{*}$ \\
\hline $\begin{array}{l}\text { Disconnect the channel plug, injection tube, and } \\
\text { special cleaning adapters. }\end{array}$ & 0 & 0.0 & 35 & 100.0 & $\overline{70.00}$ & $<0.001^{*}$ \\
\hline $\begin{array}{l}\text { Soak the endoscope in HLD solution for the } \\
\text { recommended time and temp }\end{array}$ & 0 & 0.0 & 35 & $\overline{100.0}$ & $\overline{70.00}$ & $<0.001^{*}$ \\
\hline $\begin{array}{l}\text { Flush air through the endoscope channels using } \\
\text { adapters (channel plug, injection tube, and cleaning } \\
\text { adapters) }\end{array}$ & $\overline{0}$ & 0.0 & 35 & $\overline{100.0}$ & $\overline{70.00}$ & $<0.001^{*}$ \\
\hline Immerse the endoscope in fresh sterile/potable water & 0 & 0.0 & 35 & 100.0 & 70.00 & $<0.001^{*}$ \\
\hline $\begin{array}{l}\text { Soak the valves and removable parts in HLD, then } \\
\text { flush with water and dry or steam sterilizes }\end{array}$ & $\overline{0}$ & 0.0 & 35 & $\overline{100.0}$ & $\overline{70.00}$ & $<0.001^{*}$ \\
\hline $\begin{array}{l}\text { Confirm that endoscopes and channels are rinsed with } \\
\text { sterile or filtered water after exposure to HLD, then } \\
\text { with alcohol rinse per mfr instructions, and then forced } \\
\text { air for drying. }\end{array}$ & $\overline{0}$ & 0.0 & 35 & $\overline{100.0}$ & $\overline{70.00}$ & $<0.001^{*}$ \\
\hline Automated Disinfecting & 0 & 0.0 & 35 & 100.0 & 70.00 & $<0.001^{*}$ \\
\hline
\end{tabular}

(*) Statistically significant at $\mathbf{p}<0.05$

Amer et al., Afro-Egypt J Infect Endem Dis 2019; 9(1):31-45

https://aeji.journals.ekb.eg/

http://mis.zu.edu.eg/ajied/home.aspx 
Table (8) : Nurses' practice of infection control precautions post procedure (endoscope handling and storage) throughout intervention

\begin{tabular}{|c|c|c|c|c|c|c|}
\hline \multirow{3}{*}{$\begin{array}{l}\text { Infection control precautions } \\
\text { Done }\end{array}$} & \multicolumn{4}{|c|}{ Time } & \multirow{3}{*}{$\begin{array}{l}\mathrm{X} 2 \\
\text { test }\end{array}$} & \multirow{3}{*}{ p-value } \\
\hline & \multicolumn{2}{|c|}{$\begin{array}{c}\text { Pre } \\
(\mathbf{n}=35)\end{array}$} & \multicolumn{2}{|c|}{$\begin{array}{c}\text { Post } \\
(\mathbf{n}=35)\end{array}$} & & \\
\hline & No. & $\%$ & No. & $\%$ & & \\
\hline \multicolumn{7}{|l|}{$\begin{array}{l}\text { Post procedure: } \\
\text { Endoscope Handling: }\end{array}$} \\
\hline $\begin{array}{l}\text { Ensure that the insertion tube is not coiled too } \\
\text { tightly when handling the endoscope }\end{array}$ & 0 & 0.0 & 35 & 100.0 & 70.00 & $<0.001 *$ \\
\hline $\begin{array}{l}\text { Position the control knobs upright, especially if } \\
\text { the endoscope is placed on a counter }\end{array}$ & 0 & 0.0 & 35 & 100.0 & 70.00 & $<0.001^{*}$ \\
\hline Transport the endoscope using both hands & 0 & 0.0 & 35 & 100.0 & 70.00 & $<0.001 *$ \\
\hline \multicolumn{7}{|l|}{ Endoscope Storage: } \\
\hline $\begin{array}{l}\text { Ensure that an alcohol flush was performed and } \\
\text { that the endoscope was dried with a lint free } \\
\text { cloth and alcohol }\end{array}$ & 34 & 97.1 & 35 & 100.0 & Fisher & 1.00 \\
\hline $\begin{array}{l}\text { Remove all valves and removable parts from } \\
\text { the endoscope to prevent the retention of } \\
\text { moisture }\end{array}$ & 34 & 97.1 & 35 & 100.0 & Fisher & 1.00 \\
\hline $\begin{array}{l}\text { Store the endoscope with the angulation locks } \\
\text { in the free position, in a ventilated cabinet }\end{array}$ & 35 & 100.0 & 35 & 100.0 & 0.00 & 1.00 \\
\hline $\begin{array}{l}\text { For endoscopes with flexibility adjustment, } \\
\text { ensure the insertion tube is set to maximum } \\
\text { flexibility }\end{array}$ & 3 & 8.6 & 35 & 100.0 & 58.95 & $<0.001^{*}$ \\
\hline $\begin{array}{l}\text { Hang the endoscope with the insertion tube and } \\
\text { light guide tube placed vertical (support the } \\
\text { control body) }\end{array}$ & 34 & 97.1 & 35 & 100.0 & Fisher & 1.00 \\
\hline $\begin{array}{l}\text { Disinfected scopes are properly hung and dried } \\
\text { away from dirty reprocessing areas. }\end{array}$ & 26 & 74.3 & 35 & 100.0 & Fisher & $0.002^{*}$ \\
\hline
\end{tabular}

(*) Statistically significant at $\mathbf{p}<0.05$

\section{DISCUSSION}

Gastrointestinal (GI) endoscopy is an essential tool for the identification and treatment of esophageal varices $[\mathbf{9 , 1 0}]$.

Esophageal variceal bleeding could cause shock, various infections like pneumonia, peritonitis, and blood stream infection when left untreated. Patients and their physicians should remain vigilant [4]. Over $50 \%$ of patients hospitalized due to esophageal varices are diagnosed with an infection [11]. The rate of mortality in patients with esophageal variceal bleeding is high at 20$35 \%$.

All staff in any situation where gastrointestinal endoscopy is accomplished must involve to infection control principles that will maintain a safe environment, free from the possibility of spreading disease to patients and co-workers. This is accurate nevertheless of the setting (hospital, clinic, ambulatory care center and office), relative to any and all kinds of gastrointestinal (GI) processes accomplished [12,13].

Nosocomial infection has many adverse effects on both patients and health care workers, it represents an undue economic burden, which increases the costs, hospitalization rate and need for antimicrobial medications and adds significant morbidity, and mortality [14].

The danger of infection after upper gastrointestinal (GI) tract endoscopy has been found to be infrequent; however, invasive endoscopic procedures can lead to various complications including remote bacterial infection [15]. Discussion of the results will cover four main areas in the 
following sequence: First, the demographic characteristics of the studied nurses; second, nurses' knowledge regarding esophageal varices and role of nurse's pre, during and post endoscopy; third, nurses, practice regarding infection control precaution and endoscopy disinfection; fourth, correlation between different variables.

Demographic characteristics of the current study indicate that $60 \%$ of nurses were in the age range of less than 40 years with mean age $38.7 \pm 10.7$ years. Regarding nursing qualification $88.6 \%$ of the studied nurses had Diploma in nursing while $11.4 \%$ had Bachelor in Nursing. As well as $54.3 \%$ of the study nurses had less than 10 years of experience in hematemesis unit with mean \pm SD 7.6 \pm 5.7 years. In relation to the attended training courses $51.4 \%$ received training. Regarding to hepatitis B vaccination $97.1 \%$ of study nurses received the vaccine.The current study was performed on 35 nurses employed in endoscopy units in Zagazig University Hospitals.

This is in agreement with Aby [16] in a study to assess the effectiveness of structured teaching program regarding knowledge on nosocomial infections in newborns among the staff nurses working in labour and paediatric units of selected hospitals who pointed that $78.33 \%$ of the staff nurses were females and $21.66 \%$ of them were aged between 21-30 years. Among the experience categories, 21.66 of the staff nurses had 0-5 year of experience. Same finding by Gijare [17] in effectiveness of teaching on infection control practices among health care professionals in the various general wards, private and semi-private wards and intensive care units of a tertiary care hospital who reported that the majority of the participant $(91.59 \%)$ were female nurses, who were less than 25 years of age, $56.30 \%$ were having less than one-year experience, while $30.25 \%$ were B.Sc. El-Sheikh, and Abed-Elsatar [18] in Egypt studied the effect of implementing a control action plan for infection prevention at endoscopy unit and reported that $66.7 \%$ of nurses were $<30$ years old and $33.3 \%$ was from 30 to $<40$ years old . In addition, a study carried out in Zagazig University by Ali and Taha [19] stated that the mean age of nurses was 29.5 5.76.

The current study showed that, there were highly statistically significant practice level regarding prepare and place equipment on special clean table, wear sterile gloves before procedures, during procedure: adherence to infection control principles restrictedly, post procedure pre-cleaning, leakage testing, manual cleaning, high level disinfectant (HLD), manual disinfecting, post procedure: endoscope handling when comparing with pre and post of implementation of intervention program $(\mathrm{p} \leq 0.001)$.

This finding is in concordance with Ali and Taha, [19] who indicated that there were highly significance differences through phases of study regarding knowledge and practice of universal precaution and endoscopic reprocessing between pre and post, pre and follow up $(\mathrm{P}=0.0001)$ among studied nurses [19]. In addition, a study carried out in India by Koshy and Patel [20] who pointed between the posttest and pretest knowledge scores of staff nurses regarding the infection control measures was found to be highly significant $(\mathrm{p}<0.05)]$.

On the same line with this finding were Maheswari and Muthamilselvi [21] who pointed that over all knowledge posttest mean value 699 and mean percentage $93 \%$ are higher than the pretest (the mean value 319 and mean percentage 51\%). As well Gijare [17] who reported that there was a highly significant difference in the overall knowledge and practice of infection control protocols among nurses during posttest showing that the overall effect of training was good. In this regards a study carried out in Egypt 2010 which demonstrated that there was significant difference between pretest and posttest as regard to the total knowledge score of nurses about infection prevention and control ( $p<0.001)$. The mean of total score of nurse's knowledge in posttest was higher than pretest; this indicated that improvement knowledge of nurse's after the action plan has implemented. There was a statistical significant difference between pre, and post intervention in relation to universal precaution measures and endoscope reprocessing among nurses except for wearing gloves and eye goggle. This indicates that the implementation of the action plan was very effective in enhancing physician and nurses' knowledge and practice regarding wearing personal protective equipment.

The finding is in agreement with Ali and Taha, [19] who demonstrated that $7.5 \%$ of nurses had satisfactory knowledge before implementation of the infection control training program, $75.0 \%$ after implementation program and $67.5 \%$ after 6 months of the program implementation (follow-up). In addition, more than half of nurses $(85.0 \%)$ had unsatisfactory level of practice in the pre infection control training program progressed to become 
$82.5 \%$ of them in the post program had satisfactory practice and persist in the follow-up to become $77.5 \%$ of nurses had high level of practice ( $>0.0001$ ). As well Thomas [22] who demonstrated that $4.4 \%$ of subjects had poor knowledge, $46.6 \%$ of subjects had average knowledge, $48.8 \%$ of subjects had good knowledge and none of the subjects had very good knowledge. In the posttest $65.5 \%$ subjects had gained very good level of knowledge, $33.3 \%$ of subjects gained good level of knowledge, $1.1 \%$ of subjects gained average level of knowledge, while none had poor knowledge regarding infection control.

The obtained data is in agreement with Gijare, [17] in the various common wards, who reported effectiveness of teaching on infection control practices among health care professionals and revealed that there was a highly significant difference in the overall knowledge and practice of infection control protocols among nurses during posttest showing that the overall effect of training was good .

The results are in agreement with Cherry et al., [23] who mentioned that 30 percent of all health care associated infection (HCAI) are potentially preventable by better application of knowledge and adherence to infection prevention procedures.

Barrett and Randle [24] and Creedon [25] mentioned the importance of quality of hand washing, hand cleansing and glove use indications.

This finding is opposite to study by Mohamed, [26] in Ain-Shams University who revealed sources of infection in the intensive care unit and suggested control system and found that nearly all of studied nurse reported correct answers concerning time of hand washing. In addition, the study carried by Abd-Elaziz [27] in Zagazig University Hospital, who mentioned that all nurses reported correct answers concerning the item related to time of hand washing. Moreover another study carried by Abd El-Lateef [29] and Sliman [28] in Zagazig University reported that hand washing practices are very important before and after all patient contacted; and this is the single and most significant way of avoiding infection.

These results were congruent with Elghatey et al, [30] in King Khalid University who found that $>50 \%$ of nurses had adequate knowledge before application of Universal Infection Control Intervention Program for Nurses at Asser Hospital.
In relation to precautions with sharp disposal, and precautions with blood splash on mucous membrane the current study represented that more than two fifth of nurses had knowledge pre implantation increased to all of them $100 \%$, more than two third in post and two third in follow up respectively. In the same line with these findings Abd El-Rahman [31] in Zagazig University who revealed that, majority of studied nurses had correct answers related to safe sharp disposal.

In same line Ali and Taha [19] in Elnaser Insurance Hospital at Helwan City in Egypt, who reported that it was quite anticipated to find very low levels of knowledge among the nurses in the current study before implementation of the program. This was observed in all the tested areas of knowledge (wearing protective clothes, transferring endoscope for cleaning, pre-manual cleaning stage, leak test, manual cleaning stage, rinsing, sterilization and dryness, dangerous of inadequate endoscope disinfection, storage and documentation).Similar findings were found by Ghonaiem [32], in Benha University.

On the other hand Hosney [33] in Benha University showed that there were weighty enhancements in the studied nurse's knowledge and practice after program implementation.

In addition Abd Elaziz et al. [34] in Egypt showed that there was a statistical significant differences $(p<0.01)$ between the improvement of nurse's practice and the implementation of the infection control program.

On the same line Mostufa [35] in Benha University reported significant correlation between enhancement knowledge and upgrading of practice post program.

Ghonaiem [32], in Benha university revealed that there were no important correlation between nurse's knowledge about infection control measures and age, years of experience pre and post program implementation.

On the other hand, results revealed that these finding contradicted with Majesky et al. [36] study, which indicate that neither age nor qualification, occupation and years of experience consistently proved to be a powerful predictor for nurses response.

Mohamed and Wafa [37] revealed that, there was positive statistically correlation ( $\mathrm{p}$-value $<0.01$ ) between the nurse's practice score and knowledge score pre and post implementation of nosocomial IC program. On the other hand, there was 
numerical weighty relation found between knowledge and practice as found by Ndikom \& Onibokun [38], Hamid et al. [30] and Eskander, Morsy \& Elfeky [40].

\section{CONCLUSION}

Based on the results of the present study, the following can be concluded:

There is improvement in total level of nurses' knowledge, and practice regarding caring for patient with esophageal varices during endoscopy and infection control when comparing with pre and post implementation of intervention program. There is no statistically significant relationship between improvements of nurses' knowledge and practice and their sociodemographic characteristic when comparing with pre and post implementation of intervention program regarding endoscopy infection. There was high statistical significant correlation between improvement of knowledge and improvement of practice of the nurses.

\section{RECOMMENDATION}

Based on the findings of the current study, the following recommendations are suggested :

Continuous intervention infection control training programs are recommended in endoscopy units. So incorporation of such interventions apply in all endoscopy units all over Egypt.

Hospital policy should include intervention training program, and orientation program for newly appointed employees to get oriented with the infection control standards as might that affects their performance.

Written standards procedural guideline for infection control should be available in endoscopy unit and should be up to date periodically to suite the new trends of infection prevention.

Periodic evaluation of knowledge and practices for the nurses working in endoscopy to assess what needs and appraisals.

All staff working in endoscopy unit must be medically and laboratory examined before starting employment, also periodical medical checkup should be done every six months. With Periodical vaccination for protecting medical team.
Adequate supplies, equipment and facilities should be available to encourage nurses to comply with principles of infection control precautions.

\section{Ethical Considerations:}

Nurses' oral consents were obtained before starting data collection. The aim of the study was explained to all participates. They were assured about confidentiality and anonymity of the study. They were informed about their right to refuse or withdraw from the study at any time without giving a reason.

\section{Funding:}

None.

\section{Conflicts of interest:}

There are no conflicts of interest.

\section{REFERENCES}

1. A Chana A, James M and Veale P. Anaesthesia for transjugular intrahepatic portosystemic shunt insertion DOI available at: http://dx.doi.org/ 10.1093/bjaed/mkw022 mkw022 First published online accessed on 6 May 2016 at 8 p.m

2. Villanueva C, Colomo A, Aracil C \& Guarner C. Current endoscopic therapy of variceal bleeding. Best Pract Res Clin Gastroenterol 2008; 22: 261278

3. Garcia-Pagan JC, Caca K \& Bureau C. Early use of TIPS in patients with cirrhosis and variceal bleeding. N Engl J Med 2010; 362: 2370-

4. National Center for Biotechnology Information. Bleeding esophageal varices. A A.D.A.M. Medical Encyclopedia/National Library of Medicine. Retrieved from http://www.ncbi.nlm.nih.gov/ pubmedhealth/PMH0001314/ accessed on 20 May 2016 at 11 p.m, 2014.

5. Augustin S, Gonzalez A \&Genesca J. Acute esophageal variceal bleeding: Current strategies and new perspectives. World J Hepatol. $2010 \mathrm{Jul}$ 27;2(7):261-74. doi: 10.4254/wjh.v2.i7.261.

6. Charuworn $\mathrm{P}$ and Cheung R. Screening for esophageal varices in cirrhotic patients: endoscope, platelet count, or both? Gastrointestinal Endoscopy, 2006, 64(6), 865-867

7. National Institute of Health. Bleeding Esophageal Varices. Retrieved from http://www.nlm.nih. gov/medlineplus/ency/article/000268.htm. accessed on 12 May 2016 at 7 p.m, 2015

8. Amer W, Taha N \& Zaton H. Nurses Knowledge and Practice Regarding Gastrointestinal Endoscopy and Suggested Nursing Guidelines. Afro-Egypt $J$ Infect Endem Dis 2015; 5(2): 115-130 available at http://mis.zu.edu.eg/ajied/home.aspx published online accessed on 8 May 2016 at 8 p.m 
9. Abd-Elhamid A, El-khashab N, Taha N \& Saleh M. Impact of Training Education Program on Improving of Nurses Performance Regarding Infection Control in Endoscopy Unit, Afro-Egypt $J$ Infect Endem Dis 2016; 6(1): 16-28 available at http://mis.zu.edu.eg/ajied/home.aspx published online accessed on 8 May 2016 at 8 p.m

10. Tetangco EP, Silva RG, Lerma EV. Portal hypertension: etiology, evaluation and management. Disease Mon 2016;62:411-26.

11. Augustin S, Gonzalez A \&Genesca J. Acute esophageal variceal bleeding: Current strategies and new perspectives. World J Hepatol. 2010 Jul 27;2(7):261-74. doi: 10.4254/wjh.v2.i7.261.

12. Society of Gastroenterology Nurses and Associates. Standards of infection control in reprocessing of flexible gastrointestinal endoscopes. 2012, www.sgna.org/Portals/0/sgna_stand_of_infection _control_0712_FINAL.pdf

13. Jairath V, Rehal S, Logan R. Acute variceal haemorrhage in the United Kingdom: patient characteristics, management and outcomes in a nationwide audit. Dig Liver Dis 2014; 46:419-26.

14. Rohensal VD, Guzman S \& Crinch, C. DeviceAssociated Nosocomial Infection Rates in Intensive Care Units of Argentina. Infection Hospital Epidemiology. 2012, 25(3):251-5.

15. Alwutaib AH, Abdulghafour Y.A., Alfadhli A.K., Makboul G., El-Shazly M.K. Knowledge and attitude of the physicians and nurses regarding blood borne infections in primary health care, Kuwait. Greener Journal of Medical Sciences, 2012, 2(4): 107-114.

16. Aby AR. A Study to Assess the Effectiveness of Structured Teaching Programme Regarding Knowledge on Nosocomial Infections in Newborns Among the Staff Nurses Working in Labour and Paediatric Units of Selected Hospitals In Tumkur District. International Journal of Healthcare Sciences. 2015, 3(1). 110-119

17. Gijare, M. Effectiveness of teaching on infection control practices among health care professionals. Sinhgad e Journal of Nursing, 2012, 2(2), 5-9.

18. El-Sheikh, AA. \& Abed Elsatar, OA. The effect of implementing a control action plan for infection prevention at endoscopy unit. Egyptian Journal of Nursing, 2011, 1(3), 64-84.

19. Ali ZH \& Taha, N. M. Effect of Infection Control Training Program on Performance and Microbial Results on GIT Endoscopes. Advances in Life Science and Technology, 2014, 27, 6-16.

20. Koshy S \& Patel R. Effectiveness of Planned Teaching Program on Knowledge Regarding the Infection Control Measures in Labour Room among the Staff Nurses Working in Maternity Unit in Selected Hospital of Panchmahal District. International Journal of Innovative Research and Development, 2015, 4(4).
21. Maheswari S \& Muthamilselvi G. Assess the Effectiveness of Structured Teaching Programme on Universal Precaution among Class IV Employees Working at Aarupadai Veedu Medical College and Hospital, Puducherry, India. American Journal of Nursing Research, 2014, Vol. 2, No. 2, 26-30.

22. Thomas, M. Effectiveness of a Structured Teaching Programme on Knowledge Regarding Infection Control Among the Nursing Students. Thesis. Rajiv Gandhi University of Health Sciences, Karnataka, Bangalore, 2012.

23. Cherry MG, Brown JM, Bethell GS, Nea, T and Shaw, NY. Features Of Intervention Interventions that Lead to Compliance with Hand Hygiene in Healthcare Professionals within A Hospital Care Setting. A BEME Systematic Review: BEME Guide No. 22. BEME Guide: Hand Hygiene Review, 2012, Pp 406-420.

24. Barrett R and Randle J. Hand hygiene practices: Nursing students' perceptions. Journal of Clinical Nursing; 2008, 17 (14): 1851-1857.

25. Creedon S. Health Care Workers' Hand Decontamination.23rd Ed., Philadelphia, Pa: Saunders Elsevier; Chap 131, 2007.

26. Mohamed, M. Sources of infection in the intensive care unit and a suggested control system, Master thesis, High institute of nursing, Ain Shams University. Hospital, Journal of Hospital Infection, 2009, 35: 277.

27. Abd El-Aziz EM. Assessment Of Nurse's Knowledge and Practice Related to Nosocomial Infection Control Measures at Intensive Care Unit in Zagazig University Hospital. Unpublished Master Thesis. Faculty of Nursing, Zagazig University. 2003, Pp.100-110.

28. Sliman WM. Assessment of Intensive Care Unit Nurse's Knowledge and Practice of Infection Control Precaution in Zagazig University Hospital. Unpublished Master Thesis.Faculty Of Nursing, Zagazig University. 2005, Pp.89,93-100.

29. Abd El-Lateef AM. Designing/implementing and Evaluating an Intervention Program for Prevention of Infection in Burn Unit. Unpublished Doctor Thesis. Faculty of Nursing, Zagazig University. 2003, Pp.69-70.

30. El-Ghatey A, Mahrous F and Gendy J. Impact of Universal Infection Control Intervention Program for Nurses at Asser Hospital Medical-Surgical Nursing Department, Faculty of Nursing, King Khalid University, Abha. Saudi Arabia Journal of American Science 2013;9(12) 940:948 http://www.jofamericanscience.org.

31. Abd El-Rahman AG. Assessment of Implemented Infection Control Program For Nurses in Zagazig Fever Hospital. Unpublished Master Thesis. Faculty of Nursing, Zagazig University. 2010, Pp.34-84. 
32. Ghonaiem SE. Impact of designed infection control training program of knowledge and practice at Benha University Hospital. A thesis submitted for partial fulfillment of doctorate degree, faculty of nursing, Benha University, 2011.

33. Hosney Z. Effect of Designed Implemented Nurse's Intervention Program on Minimizing Incidence of Complications for Patients With Upper Gastrointestinal Bleeding. Doctorate Thesis, Faculty of Nurses, Benha University, 2014.

34. Abd Elaziz, M., Soliman, R,A., and El lawindi, M. Evaluation of an Isolation Program of Hepatitis C Virus Infected Hemodialysis Patients in Some Hemodialysis Centers in Egypt. ISRN Nephrology, Volume 2013 (2013), Article ID 395467, 5 pages. Available at: http://dx.doi.org/ 10.5402/2013/395467.

35. Mostufa MM. Improve the Quality of Nurses' Performance to Provide Client Satisfaction in Kidney Dialysis, Doctorate Thesis, Faculty of Nurses, Benha University, 2009.
36. Majesky S, Brester M and Nishio K. Devolpment Of A Research Tool: Patient Indicators of Nursing Care. Nursing Research, NovemberDecember; 2005, Vol. 27(6): 365-710.

37. Mohamed SA and Wafa AM. The Effect of An Intervention Program on Nurses Knowledge and Practice Related to Hepatitis C Virus: A Pretest And Posttest Quasi-Experimental Design. Australian Journal of Basic and Applied Sciences, 2011, 5(11): 564-570, 2011 ISSN 1991-8178.

38. Ndikom CM and Onibokun A. Knowledge and behaviour of nurse/midwives in the prevention of vertical transmission of HIV in Owerri, Imo State, Nigeria: a cross-sectional study. $B M C$ Nursing, 2007, 6(1), 9.

39. Hamid MZA, Aziz NA, Anita AR, Norlijah O. Knowledge of blood-borne infectious diseases and the practice of universal precautions amongst health-care workers in a tertiary hospital in malaysia. Southeast Asian J Trop Med Public Health, 2010, 41(5): 1192-1199.

40. Eskander HG, Morsy WYM \& Elfeky HAA. Intensive Care Nurses' Knowledge \& Practice Regarding Infection Control Standard Precautions at a Selected Egyptian Cancer Hospital. Journal of Education and Practice, 2013, 4(19), 160-174. 